Original scientific paper

\title{
CONTRADICTIONS OF MEDICAL TOURISM
}

\author{
Martin ZSARNOCZKY \\ ${ }^{a}$ Szent István University, Enyedi György Doctoral School of Regional Sciences, email: \\ martin@aunaturel.hu
}

Cite this article: Zsarnoczky, M. (2016). Contradictions of Medical Tourism. Deturope, 8, 3: 212-223

\begin{abstract}
Industries have to face continuously emerging new trends and challenges worldwide. The former pattern of local bundling techniques cannot seem to be adapted at global measures. The processes of globalisation urgently call for the harmonisation of legislative policies and practices. A good example for this is the current situation of health tourism. In the most rapidly changing industry, development has overcome legislation by far, and unfortunately left policy makers and local stakeholders unable to respond to the new challenges. However, the continuous growing on the demand side forecasts further massive development of the field in the coming decades. My research focuses on this contradictory situation: I try to find out whose responsibility is it to force the creation of a unified legal background: the supply side that offers a wide variety of different services or the rather vulnerable supply side that needs a transparent quality assurance system to be protected.
\end{abstract}

Keywords: health tourism, international healthcare, medical tourism, silver tourism, patient follow-up

\section{INTRODUCTION}

The standard worldwide harmonisation of different national healthcare systems and their quality assessment methods have been considered an unresolved issue for a long time. Similarly, it has been a hot topic of many professional disputes that the provisions and evaluation methods of national public healthcare systems should be made comparable. There is a strong need to develop a common standard that can be used by patients, health insurance companies, social security services and ministries of health globally. Private companies operating in different countries also need to have a comparable standard urgently, because "high tech" medical and health services have overgrown the boundaries of the public sector and become one of the fastest developing business sectors.

In the past 50 years, several excellent examples of healthcare quality standards have been developed that are nowadays used for the comparison of accredited healthcare providers located in different continents. Due to lack of uniform international legislation, stakeholders of the industry use their own local regulations, which are not necessarily compatible with each other. One of the safest healthcare systems is insurance-based service purchase. The most important element of such a system should be that service providers that are able to ensure 
long term high quality services are given preference when contacts are concluded. It is obvious today that the former "Western-welfare" healthcare provider systems cannot be solely publicly funded; they need to be operated - at least partially - on market terms or/and by outsourcing (Ben-Natan et al, 2009). Economic experience shows that "the state" is significantly less successful in healthcare management than profit-oriented market actors; due to this fact, there are enormous differences in the quality and accessibility of services offered by public healthcare providers. According to market actors, it is high time that the costeffectiveness of these services were measured. It is interesting to note that in the case of the most successful healthcare sectors, the role of public bodies has not decreased at all. On the contrary: recent trends show that countries previously known for their not so strictly regulated healthcare system (e.g.: the USA), are starting to handle the sector's public control as a priority. At the same time of the introduction of OBAMACARE, other countries also have to deal with the quality assurance issues of their healthcare systems. The health tourism industry is based on these worldwide health service trends; within the sector, not only national service providers compete with each other, but the whole world has become one giant marketplace.

Within health tourism, medical tourism generally refers to the travel of people to another country for the purpose of obtaining medical treatment abroad. There could be different reasons for travelling abroad for healthcare services. These may include services from the whole public and private spectrum of the healthcare industry, i.e.: health, medical, wellness, spa, wellness and/or holistic services. The most common reasons can be the lower costs of specific treatments, shorter waiting lists or easier accessibility of the required services. The number of medical tourists travelling for such reasons is foreseen to increase exponentially in the near future, and they already represent a significant demand on the market, always seeking the best available services. My research focuses on how legal, warranty, insurance and quality assurance rights of customers can be applied in the environment of international health tourism, where the legal background is different in almost every country especially in the case of public and private institutions.

\section{OBJECTIVES AND METHODS}

\section{Summary of related literature}

The industry of health tourism is foreseen to grow dynamically in the near future (Aubert \& Berki, 2007; Botterill et al., 2013). The measure of impact of tourism is determined by its development level, the types of tourists and by the attitude of local stakeholders (Murphy, 
2013). Due to the complexity of health tourism, there is no common international definition of the term (Rulle \& Brittner, 2011). Health tourism includes medical, preventive and recreational tourism, where the main motivation is the improvement and/or maintenance of one's health, for which people will obtain health tourism services whilst their stay at the destination (Cassens et al., 2012). Within the frameworks of health tourism, tourist will obtain medical services (e.g. dental treatments, ophthalmological services, plastic surgery, etc.) (Bookman \& Bookman, 2007). Due to its impact on healthy lifestyle and health related product groups, the significance of health tourism goes beyond the tourism sector; therefore, the "successfulness" of the country has become more important than ever (Chew, 2010).

\section{Research and analysis methods}

My research aims to tackle one of the most topical issues; mostly because in health tourism, the stakeholders (both on the demand and supply side) are regulated by local and national legislation, according to their official location. There are quite few commonly accepted international standards in existence within the industry, except for the regulation of international franchise rights. The fact that a leading international industry like health tourism does not have a common global legislative system may lead to the risk that patients will have no guidelines whilst decision making, and they can be easily misled by "self-appointed counsellors" when problems arise. Unfortunately, there are no uniform guidelines that would inform health tourists about different countries' regulations regarding health service institutions' qualification as private or public providers. What makes the situation often more complicated is that in many cases, private doctors sometimes perform some specific examinations or treatments in public institutions.

My research is based on qualitative analysis, because this method provides space for the independent thoughts and opinion of respondents (Macdonald et al. 2008). Among the numerous qualitative research tools, interviews are one of the most common methods, with semi-structured interviews being the most popular type (DiCicco-Bloom et al. 2006). This method gives an insight into the attitude of respondents towards a specific topic, and it is also an efficient tool to get to know their opinion and impressions. Whilst preparing a semistructured interview, it is of key importance to choose the most suitable interviewees and questions, because such interviews are to be organised around pre-specified open questions that leave space for further spontaneous ones. Due to lack of uniform international legislation and because the topic of my research requested the summary of personal professional 
experiences, my 16 interviews were organised with leading high official tourism professionals and physicians of public and private health institutions. The questions of the interviews focused on the contents of services, the relationship between quality and price, and the demographic characteristics of the demand side. My research aimed to answer questions related to quality assurance in a mixed system of private and public service providers.

\section{RESULTS}

Existing within the frameworks of health tourism, medical tourism refers to such a complex term that there is still no common understanding on where it exactly belongs within the health and/or tourism sector. When referring to the same service, there can be significant differences in the international market and even within domestic markets. What seems to be of common agreement is that medical tourism always includes some kind of medical treatment or service that normally belongs to the health sector. From the aspect of health services, "health tourism" seems to be the correct term, including not medical, but wellness, recreational, rehabilitation services. Taking into account the terminology, this could be true; however, recent trends show that medical tourism service providers have developed mass services in some destinations because some service areas (e.g. Botox treatments) have become more profitable than the traditional infrastructural investments in tourism services themselves. Because the larger profit lies in the medical services instead of tourism developments, investors tend to prefer multifunctional destination development over pure infrastructural investments. Due to the increased competition, existing destinations like international hotel chains started to establish new brands of spa-wellness services operating as franchise systems within their facilities (Six Senses, 2013).

According to the recent statistics of receiving countries, the most popular services within health tourism are orthopaedic surgery, plastic surgery, cardiologic treatments, oncological treatments, dental treatments, reproductive treatments, organ transplantation (Connell, 2006) and gene therapy procedures which often raise legal concern.

The most popular destinations are Thailand, Mexico, Singapore, India, Malaysia, Cuba, Brasilia, Argentina, Costa Rica and Central-eastern European countries. The latter, combined together represent a significant market, mostly due to their unbeatable prices. There is of course a fierce competition for consumers among the destinations that offer high quality services. The huge demand for health tourism services and the intense competition between providers is also reflected in an article by Forbes magazine. According to the journal, in 2013, 
40 million U.S. citizens did not have any health insurance, and around 120 million of them lacked dental insurance. In 2012, 1.6 million U.S. citizens obtained health services in health tourism destinations, resulting in a total spending of 35 billion USD.

Figure 1 Central-European medical tourism TOP 5 destination countries

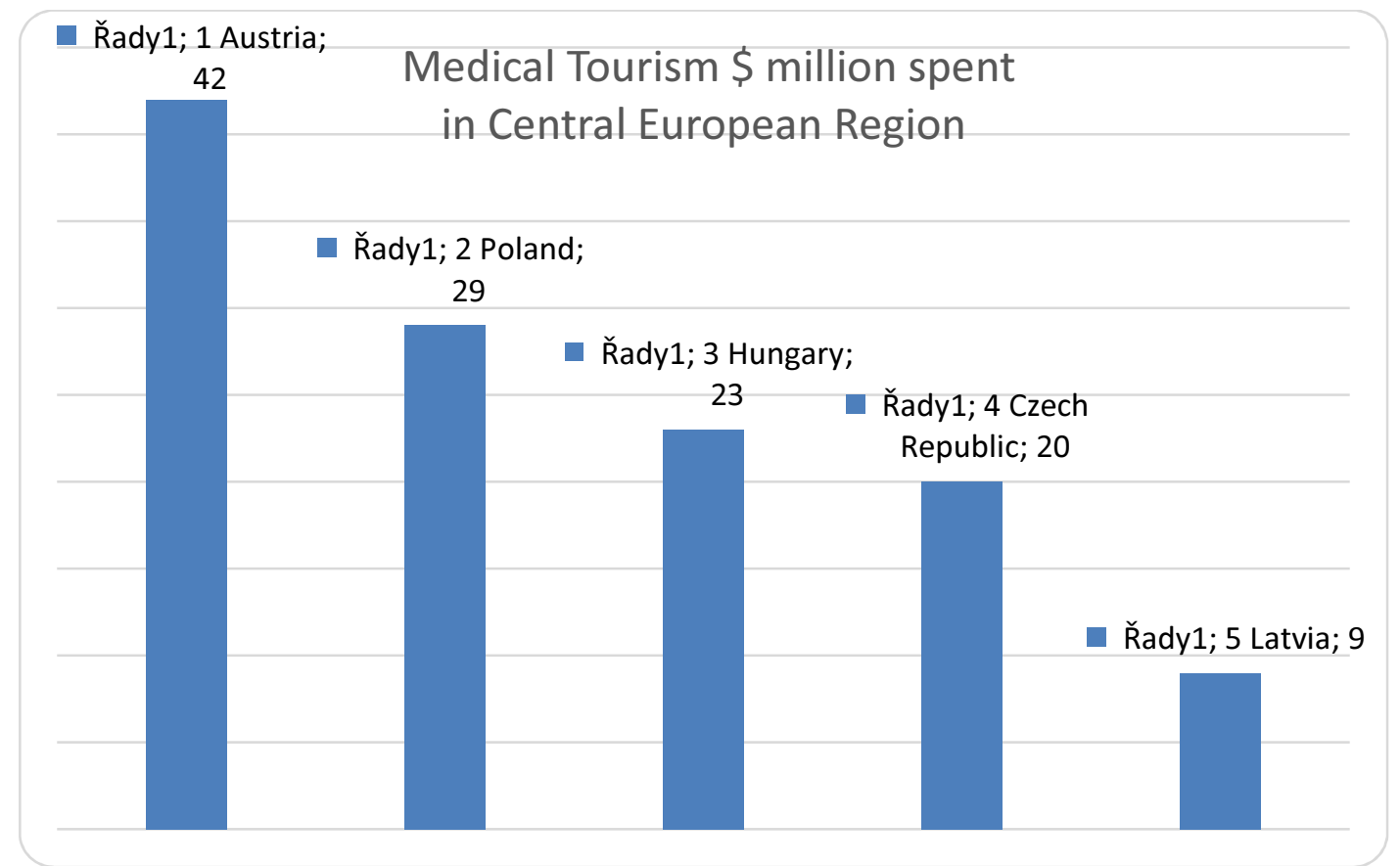

Source: KPMG Counsulting, own edition

In 2007, a study published by Roland Berger Strategy Consultants on European healthcare set out the following strategic objectives for healthcare industry service providers: excellent management, complex product mix, conscious lifestyle development, increased specialisation, measurability of value-for-money, development of independent institutional standards, extension of private institutions, development of joint products in accordance with market demands, inter-institutional mobility. It is clear that in the past decade, traditional healthcare providers did not benefit much from these trends, while health and medical tourism service providers were able to achieve significant results.

The correct definition of the demand side has become a key factor for the stakeholders of the industry, because effective strategic development requires and in-depth knowledge about the characteristics of medical tourists. Medical tourism offers several benefits for service consumers like lower costs or shorter waiting lists.

Medical tourists will expect the services to be at least the same quality or better than in their home country (Horowitz \& Rosensweig, 2007; MacReady, 2007). It is commonly agreed 
that the majority of medical tourists have experience in health services, and already had some kind of health insurance in the past.

Figure 2 Savings on healthcare services in relation with the price levels of the USA

\begin{tabular}{|c|c|}
\hline Country & $\begin{array}{c}\text { Estimated savings } \\
\text { on healthcare services } \\
\text { USA }=100 \%\end{array}$ \\
\hline India & $65-90 \%$ \\
\hline Malaysia & $65-80 \%$ \\
\hline Thailand & $50-70 \%$ \\
\hline Turkey & $50-65 \%$ \\
\hline Mexico & $40-65 \%$ \\
\hline Costa Rica & $40-65 \%$ \\
\hline Taiwan & $40-65 \%$ \\
\hline Singapore & $30-45 \%$ \\
\hline Korea & $30-45 \%$ \\
\hline Brazil & $25-40 \%$ \\
\hline
\end{tabular}

Source: Devon M. Herrick, own edition

According to research results based on the experience of professionals, the majority of medical tourists belong to the 50+ age group in need of some kind of health services (Public Citizens Health Research Group, n.d.). In Europe, the 50+ age group of the society and its related sector have been already named "silver economy" (Zsarnoczky, 2016a). Silver economy represents an important economic factor that no service provider wants to miss out on. According to demographic data, the number of senior citizens is not only increasing, but due to less physical stress and the effects of social welfare, the ratio of old people will also grow within the group of senior citizens - in the Far East, the "Methuselah" (95+) age group already represents a clearly measurable demographic segment. 
Figure 3 Segments of the silver economy

\section{ECONOMIC SEGMENTS OF THE SILVER ECONOMY}

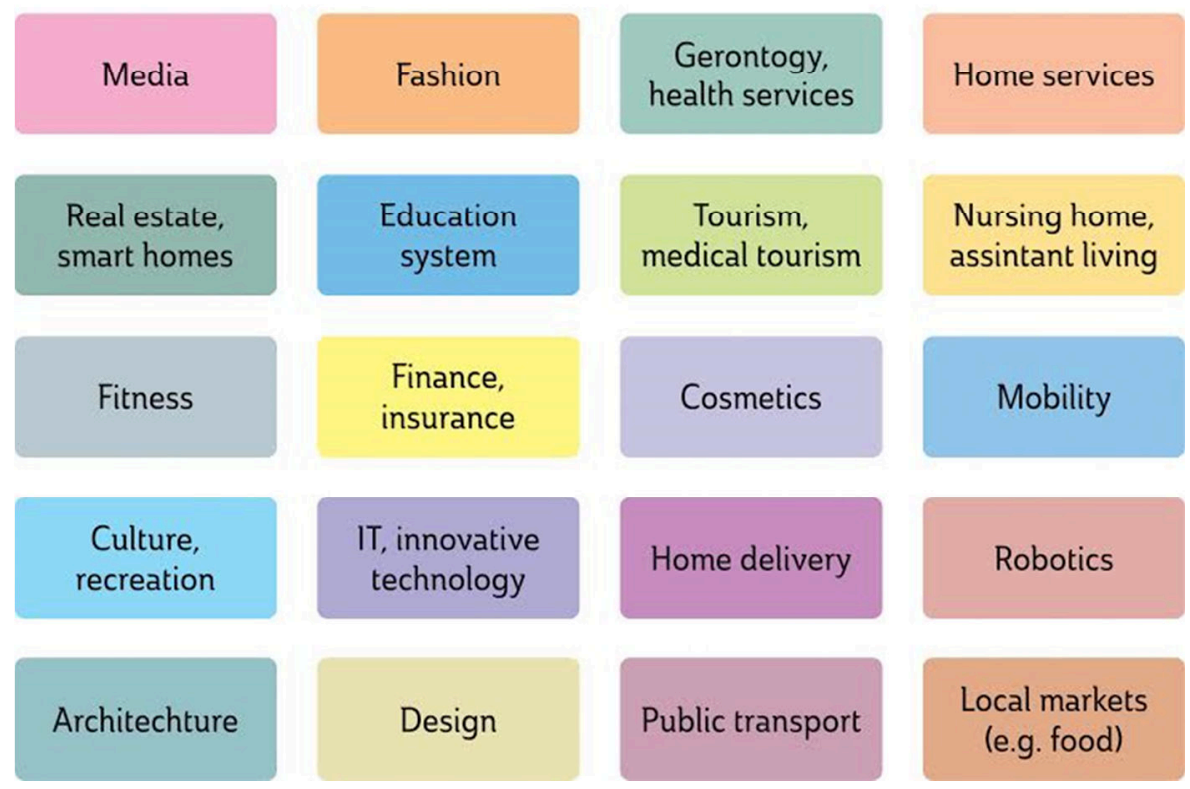

Source: Zsarnoczky, M (2016b)

Previously, marketing professionals misunderstood the characteristics of the sector and thought of it as a homogenous group. The members of the silver economy who use the services of silver tourism have secured income resources and can afford healthcare services related to tourism.

General characteristics of silver tourists (Zsarnoczky, 2016c);

- they have sufficient discretionary income,

- $\quad$ based on demographic data, the majority of silver tourists are women,

- $\quad$ safety is a priority for them, they avoid disaster areas,

- $\quad$ they have more free time, thus they are willing to travel at any season of the year,

- they can and are willing to extend the length of their stay, even at multiple times,

- $\quad$ they belong to the group of 'curious tourists',

- $\quad$ they need more communication,

- $\quad$ they are willing to buy medical and recreational services,

- when choosing their means of transport, accessibility is more important than the type of vehicle,

- $\quad$ Europe is their priority destination.

Today, based on market demands, several intermediating companies operate between service providers and patients/tourists (Mintel, 2013). The competition on the supply side is 
fierce, with all interested parties willing to benefit from their own advantage. Due to the fact that a huge expansion is foreseen both on the demand and supply side, there is a strong need to develop a unified international standards system. Such an up-to-date standardised system should serve as the basis of a mandatory health service accreditation system. The introduction of a healthcare accreditation system could be an excellent tool of ensuring transparency and security within the sector. Currently, there are several different standards existing on the healthcare market; the introduction of any of them as an international standard would have many positive effects. The development of international healthcare standards - similarly to many successful bottom-up incentives - originates from the USA. The idea was created in the 20th century by U.S. physicians who worked in an environment that was based on European traditions but was operating by clear market principles. The main objective of creating such standards was to ensure professional quality and better services. Of course, a lot of effort was put into the dissemination of the newly developed standards among patients. Based on the idea of comparativeness, the American Surgery Society, the American Medical Association, the American Physicians Association and the Canadian Medical Association established the Joint Commission on Accreditation of Hospitals, JCAHO at the early 1950s. The incentive aimed to develop a standardised assessment system that would be suitable for the evaluation of the hospital structure and healthcare process management of all participating organisations. In the next decade, by the introduction of the Medicare programme (established in 1965), the incentive reached and institutionalised status. In the late 1980s, the organisation's name was changed to Joint Commission Resources (JCR), and its activity was expanded to most healthcare providers. By time, the focus of evaluation moved towards effective management and the continuous improvement of productivity. Within the frameworks of the so-called "Agenda for Change", a new structural key point was set out for healthcare providers: the general quantitative and qualitative revision of standards.

Today, it is a basic principle and key expectation of local health funds in the European Union that - due to the mobility of patients - healthcare services provide a guaranteed quality of services. During the development of national accreditation standards, the most important processes have been set out with regards to the effectiveness and safety of services and patients' rights. In theory, the standards ensure that service providers take up only those patients whose needs can be answered by the given institution and that service providers could deliver continuous and effective services for them. Also, the dismissal of patients should be planned on the basis of quality standards. If accreditation processes focused on the reduction of anomalies and administrative workload, both the reliability and authenticity of 
healthcare programmes would increase significantly. It is interesting to note that the existing standards not only focus on informing patients, but also suggest their education about prevention.

Health tourists usually end up with private institutions in different countries; therefore it is recommended that those institutions have the appropriate international contracts and documents, and employ effective medical management staff. Because lower costs are among health tourists' primary expectations, it is also advised to clarify the possible contradictions of cost effectiveness and explain whether cheaper services mean lower quality, or how costeffectiveness is achieved. In our world of mass information, health service websites offer hardly any information on the rights of patients. Although medical science is built on uniform pronciples, the definition of quality has many differences worldwide. The term 'quality' not only refers to the standard of a product or material, but is also relevant in the case of services. Looking one step further, the establishment of uniform quality standards will lead towards assessment and monitoring issues. The main problem is that there is (and probably will be) a huge difference between the quality of services guaranteed by public and private institutions. It is possible that some health tourism destinations, which have a high number of stakeholders, will apply their own 'regional' quality standards. But why is the comparability of quality standards so important? On one hand, a uniform system can reveal previously unseen internal differences, which can lead to the improvement of services. For the demand side, a trustworthy quality assurance system can offer clear information on patients' guaranteed insurance rights in case of a possible medical complication. For example, in public hospitals in the EU, domestic and EU-citizen patients are guaranteed the same services, whilst patients from third countries are treated under different conditions. On the other hand, private health providers can operate within the framework of a uniform quality assurance system that enables the comparability of prices and services worldwide. It is clear that measurability and audition is in the common interest of all stakeholders. The development of such an assurance system might be expensive, but it can surely reveal the difference between cost-effective and low cost services. A health institution accredited by an internationally acknowledged quality assurance system will have significant market benefits.

Some of the websites that I looked into during my research provided some information about the qualification of health service professionals, but I could not get any information on who is responsible for which service within the chosen institution. In a giant medical complex like for example the Texas Medical Center - which consists of 54 institutes, 21 hospitals, 8 research centres, 4 medical schools, 6 nurse training schools and other training facilities - 
there is practically no opportunity to establish a personal doctor-patient relationship in advance. With regards to patient rights, interesting problems can arise from the fact that insurance companies cannot have an insight into the services obtained by their clients, because of medical secrecy; for the same reason, international private health institutions are often not obliged to inform insurance companies about the exact details of their services.

It is clear that an internationally standardised healthcare follow-up system would be in the common interest of insurance companies, patients and service providers alike. It is interesting to note that the vast majority of the interviewed professionals said that ON THEIR OWN RESPONSIBILITY, patients basically can choose whichever service they like. However, due to the differences between service providers, the quality of these services may differ significantly. The place and time, the physical and mental status of the patient are all related to the process of healing, too. It could significantly decrease insecurity in the market, and in case of a medical error, neither the service providers nor patients could deny what happened. With such a follow-up system, special cases could be investigated effectively like problems caused by local bacteria (e.g.: the bacteria concentration in the air is extremely high in India) or a thrombosis during the flight home.

\section{CONCLUSION}

There are several different arguments for and against healthcare accreditations, both at local and international level. Most private healthcare service providers are interested in the establishment of a transparent follow-up system, which would measure the strengths and weaknesses of services, on the basis of internationally agreed accreditation standards. Such a system would result in higher quality, more efficient and profitable services. Fewer aimless political decisions and an increased market competition would contribute to costeffectiveness; the reputation of physicians and medical service providers could be measured; the databases set up within the frameworks of an accredited system would enable objective comparisons. The reduction of medical errors and legal actions is of common interest of all service providers. With sufficient social education and other national consultation actions, the trust of local people could be restored in their own national healthcare system; also, a manager-type leadership could effectively use the tools of lobbying. Maybe the reasons behind some providers' cost-effectiveness could be clarified. It is also possible that by large scale outsourcing, some regions would become key medical destinations. An international patient follow-up system would definitely be supported by the financing and professional side 
alike. An internationally standardised comparative system would highly contribute to the budget optimisation of the sector's stakeholders worldwide. The dignity and rights of patients would also profit from such an incentive, whilst the exploitation of resources would be optimised, too. As a result, national healthcare service providers would become significantly more competitive.

\section{REFERENCES}

Aubert, A., \& Berki, M. (2007). A nemzetközi és a hazai turizmus területi folyamatai, piaci tendenciai a globalizáció korában. (Regional processes of international and domestic tourism in globalisation.) In: Földrajzi Közlemények, 3. Budapest. 119-131.

Ben-Natan, M., Ben-Sefer, E., \& Ehrenfeld M. (2009). Medical Toursim: A New Role for Nursing? OJIN: The Online Journal of Issues in Nursing, Vol. 14, No. 3.

Bookman, M. Z., Bookman, \& K. R. (2007). Medical tourism in developing countries. Palgrave Macmillan, 86(2), New York, 7677.

Botterill, D., Pennings, G., \& Mainil, T. (2013). Medical tourism and transnational health care. Palgrave Macmillan, New York, 272.

Cassens, M., Hörmann, G., Tarnai, C., Stosiek, N., \& Meyer, W. (2012). Trend Gesundheitstourismus. Prävention und Gesundheitsförderung, 7(1). 24-29.

Chew, G. L. (2010): Health care and tourism: Evidence from Singapore, Tourism Management, 31. 486.

Connell, J. (2006). Medical Tourism: Sea, sun, sand and ... surgery. Tourism Management 27 (6), 1093-1100

Devon, M. H. (2007). Medical Tourism: Global Competition in Health Care. NCPA Policy Report No. 304. Dallas.

DiCicco-Bloom, B., \& Crabtree, B. (2006). The qualitative research interview. Medical Education, 4. 314-321. http://doi.org/fhwt96

Horowitz, M.D., \& Rosensweig, J. A. (2007). Medical tourism - Health care in the global economy. The Physician Executive, 12. 24-30

International Society for Quality in Health Care (2007). Published: 01/12/2007 http://www.isqua.org/docs/default-source/accreditation/international-accreditationstandards-for-healthcare-external-evaluations-3rd-edition---b.pdf?sfvrsn=0

International Society for Quality in Health Care (2007). Published: 01/12/2007 $\mathrm{http}: / / \mathrm{www}$.isqua.org/docs/default-source/accreditation/international-principles-forhealthcare-standards---b.pdf?sfvrsn=0

Macdonald, S., \& Headlam, N. (2008). Research methods handbook. Introductory guide to research methods for social research. Centre for Local Economic Strategies, Manchester

MacReady, N. (2007). Developing countries court medical tourists. Lancet, 369, 1849-1850

Mintel (2013). Medical tourism in Asia 2013.

Murphy, P. E. (2013). Tourism: A community approach. (4). London, New York. 196.

Oleszczuk, L. (2013) Central Europe Becoming A Big Destination For Medical Tourism. Published: 22/10/2013. http:/www.forbes.com/sites/luizaoleszczuk/2013/10/22/centraleurope-becoming-a-big-destination-for-medical-tourism/

Public Citizens Health Research Group, n.d. Patients without borders: The emergence of the medical tourism. Retrieved http://www.citizen.org/hrg/article_redirect.cfm?ID=16777

$18 / 02 / 2016$ 
Roland Berger Strategy Consultants (2007) Trends in European health care. Published: 09/2007

https://www.rolandberger.com/media/pdf/rb_press/RB_Trends_in_European_healthcare 20070901.pdf

Rulle, M., \& Brittner W. A. (2011). Gesundheitstourismus. Aufl. 1, München, Wien, Oldenbourg. 250.

Six senses (2013) http://www.sixsenses.com/home; http://www.franchiserankings.com /reviews-and-ratings-of-best-spa-franchises

Nursing School Hub (2013). http://nursingschoolhub.com /medical-tourism/

Texas Medical Center (2016). http://www.texasmedicalcenter.org/institutes/

Zsarnoczky, M. (2016a). Innovation Challenges of The Silver Economy. Vadyba Journal of Management 2016, № 1 (28). Klaipeda, 105-110

Zsarnoczky, M. (2016b). The New Hope for the EU - Silver Economy. Regional Studies Association. Full Papers - RSA Annual Conference Graz 2016. Graz.

Zsarnoczky, M. (2016c). Silver Tourism. International Scientific Days 2016, The Agri-Food Value Chain: Challenges for Natural Resources Management and Society, Nitra. doi:http://dx.doi.org/10.15414/isd2016.s7.15 